\title{
Aansturing van zelfstandige bestuursorganen door ministeries: stijlverschillen
}

\author{
Sandra van Thiel \& Ron Hendriks
}

\begin{abstract}
Ministeries verschillen in de wijze waarop ze de sturingsrelatie met zelfstandige bestuursorganen inrichten en onderhouden. Aan de hand van zes cases bij vier ministeries laten we deze verschillen zien. Daarbij wordt gebruikgemaakt van twee theoretisch modellen (de principaal-agent- en principaal-steward benadering) om het soort relatie te duiden. Ministeries verschillen niet alleen hun benadering, maar ook in hoe ver ze zijn in de ontwikkeling van hun sturingsrelaties met ZBO's. Omdat er geen coördinatie of uitwisseling van kennis plaatsvindt tussen ministeries, kunnen 'achterblijvende' ministeries echter niet leren van de ervaringen van ministeries met meer ervaring. Dit artikel pleit niet voor centrale coördinatie of één model, maar wel voor het meer uitwisselen van kennis tussen en binnen ministeries.
\end{abstract}

\section{Inleiding}

Recent is in twee rapporten kritiek geuit op de wijze waarop ministeries de sturingsrelatie met zelfstandige bestuursorganen (ZBO's) ${ }^{1}$ inrichten en onderhouden. De kritiek richt zich op twee punten. Ten eerste zijn er grote verschillen tussen ministeries en zelfs binnen ministeries tussen directoraten-generaal die verantwoordelijk zijn voor bepaalde beleidssectoren (zie POC, 2012:80). En ten tweede omdat ministeries sterk verschillen in de kwaliteit van hun sturingsrelaties: 'Op sommige departementen [...] is recent een flinke slag gemaakt in het professionaliseren van de sturingsrelaties. Op sommige andere departementen is nog sprake van een grote terughoudendheid om te spreken in termen van [...] “opdrachtgeverschap”...' (Rapport De Leeuw, 2013:28). In beide rapporten wordt aanbevolen om meer kennis over dit onderwerp uit te wisselen tussen de ministeries, al dan niet via een speciaal expertisecentrum. Ook in evaluaties van individuele ZBO's wordt veel geklaagd over de relatie met het moederdepartement (Van Thiel e.a., in review). Soms wordt er teveel gestuurd (te gedetailleerde afspraken), andere keren te weinig, of alleen als er problemen zijn. Ook wordt meermaals vermeld dat het moederdepartement de kennis ontbeert om goede afspraken te kunnen maken (vgl. Van Thiel, 2010; Homburg \& Van Thiel, 2002).

1 ZBO's zijn bestuursorganen van de centrale overheid, die bij wet zijn ingesteld of aangewezen om een publieke taak uit te voeren, zonder direct ondergeschikt te zijn aan de minister. Het ZBOregister telt momenteel 118 ZBO's of clusters van ZBO's, zoals de AFM, het UWV, de RDW, het Kadaster, de Kamers van Koophandel, de Raad voor Rechtsbijstand, de Nederlandse Zorgautoriteit, en de Grondkamers. In absolute aantallen gaat het om meer dan 700 organisaties. 
Het kabinet lijkt deze mening echter niet te delen. Zij stellen: '[o]p het gebied van verbetering van de relatie tussen beleid en uitvoering zijn de afgelopen jaren door opeenvolgende kabinetten talrijke initiatieven ontwikkeld en verbeteractiviteiten in gang gezet. Departementen beschikken inmiddels over goede instrumenten (prestatieafspraken, protocollen, toezichtvisies, e.d.) op het gebied van governance ten aanzien van verzelfstandigde organisaties.' (Kabinetsreactie, 2012, p. 11). In de reactie op het rapport De Leeuw kondigt het kabinet wel aan dat er een circulaire zal komen over de governance van ZBO's, maar uit de rest van de reactie spreekt waardering voor de bestaande differentiatie van sturingsinstrumenten (Ministerie BZK, 2014, p. 6).

In dit artikel proberen we meer duidelijkheid te krijgen over dit onderwerp. Hoe is de sturingsrelatie tussen ZBO's en moederdepartementen ingericht, welke verschillen zijn er, en hoe kunnen die worden verklaard? Daarvoor gaan we eerst in op twee theoretische modellen voor deze relaties: de principaal-agent- en principaal-stewardbenadering. Aan de hand van deze twee modellen zullen we de relaties tussen vier ministeries en zes ZBO's beschrijven (vgl. Hendriks, 2013), en verschillen en overeenkomsten daarin duiden. Aan de hand daarvan kunnen we in de conclusie uitsluitsel geven of de kritiek op de sturingsrelaties gerechtvaardigd is, en zo ja op welke punten verbetering aangebracht kan worden.

\section{Sturingsmodellen}

Het traditionele model om de relatie tussen een $\mathrm{ZBO}$ en ministerie te beschrijven, is het principaal-agentmodel. Dit is een economisch model dat uitgaat van een principaal (ministerie) die een agent (ZBO) 'inhuurt' om tegen een vergoeding een bepaalde taak uit te voeren (zie bijv. Besley, 2006; Laffont \& Martimort, 2002; Hendrikse, 1993; Pratt \& Zeckhauser, 1991). Afspraken daarover worden contractueel (bijv. subsidiebesluit, convenant, managementcontract) vastgelegd. De principaal-agentbenadering gaat uit van rationele actoren die elk hun eigen doelen (nut) nastreven: de principaal wil zoveel mogelijk taakrealisatie voor zo laag mogelijke kosten, terwijl de agent zo hoog mogelijke inkomsten wil voor zo weinig mogelijk activiteit. Hun doelen zijn dus niet congruent. De agent beschikt over meer expertise en kennis dan de principaal, en kan gebruikmaken van deze kennisvoorsprong (informatie-asymmetrie) om zijn eigen doelen te realiseren. Dit kan op twee manieren: (1) door zich beter voor te doen dan feitelijk waar is, waardoor de principaal niet kan beoordelen wat de meeste geschikte agent is (adverse selection) $)^{2}$ en/of (2) door minder activiteiten te verrichten dan was afgesproken (moral hazard). De principaal kan het gedrag van de agent moeilijk beoordelen, maar hij kan zijn onzekerheid hierover verminderen door de agent te controleren of te dwingen tot verantwoording (monitoring), dan wel de agent proberen te prikkelen met een beloning of straf (incentives). De principaal zal in een dergelijk situatie veel controle- en motiveringskosten moeten maken om de

2 In het publieke domein is niet altijd sprake van echte keuze: ministerie en ZBO verkeren vaak in een bilateraal monopolie. 
agent aan te kunnen sturen en in sommige gevallen te kunnen dwingen werkzaamheden uit te voeren. Hiervoor worden contractrelaties aangegaan zodat de principaal zeker gesteld kan worden dat de werkzaamheden worden uitgevoerd.

De toepassing van dit model op relaties tussen organisaties in het publieke domein is niet zonder problemen, en ook niet zonder kritiek (zie bijv. Miller, 2005). Zo wordt bijvoorbeeld gesteld dat publieke organisaties zoals ZBO's minder gedreven worden door eigenbelang dan het model veronderstelt; zij willen juist het algemene belang dienen. Een complicatie bij de toepassing van het model is bovendien dat politieke principalen meerdere rollen vervullen: ze maken beleid, bepalen wie dat uitvoert, financieren de uitvoering, en houden er toezicht op. ${ }^{3}$ In feite heeft een $\mathrm{ZBO}$ dus te maken met meerdere principalen - helemaal als het ZBO voor meerdere ministeries werkt, iets wat steeds vaker voorkomt, door fusies en de vorming van shared service centers. Tot slot wordt door de critici opgemerkt dat het principaal-agentmodel geworteld is in hiërarchisch denken en wantrouwen en dat dat eigenlijk geen goede basis is voor publieke organisaties die met elkaar moeten samenwerken (Schillemans, 2010; Van Thiel, 2008).

Met name in reactie op dat laatste punt wordt de laatste jaren een ander model meer naar voren geschoven als een meer geschikt alternatief: het principaalstewardmodel (Davis et al., 1997; Block, 1996). Ook dit is een economisch model waarin een principaal een uitvoerder 'inhuurt' maar deze steward (in het Nederlands: rentmeester) heeft geen ander doel dan het dienen van de principaal. Er is dus geen doelincongruentie, en bijgevolg heeft de informatie-asymmetrie - die wel blijft bestaan - geen desastreuze gevolgen meer. Uitgangspunt voor dit model is wel dat de principaal de steward vertrouwt en dus niet overdreven gaat monitoren wat de steward doet (vgl. Van Thiel, 2011). De principaal-stewardbenadering maakt gebruik van een aantal psychologische inzichten, met name over motivatie en risico-oriëntatie. Tabel 1 vat de verschillen tussen beide benaderingen kort samen.

Tabel 1: Vergelijking tussen principaal-agent- en principaalstewardbenadering

\begin{tabular}{lll}
\hline & Principaal-agent & Principaal-steward \\
\hline Uitvoerder gericht op & Eigenbelang & Gedeeld (publiek) belang \\
$\begin{array}{l}\text { Motivatie van uitvoerder } \\
\text { Identificatie door uitvoer- }\end{array}$ & $\begin{array}{l}\text { Extrinsiek (prikkels) } \\
\text { der met principaal }\end{array}$ & $\begin{array}{l}\text { Intrinsiek (autonomie) } \\
\text { machtsafstand) }\end{array}$ \\
$\begin{array}{ll}\text { Management filosofie van } \\
\text { principaal }\end{array}$ & $\begin{array}{l}\text { Gericht op controle, } \\
\text { beheersen van kosten, en } \\
\text { korte termijn }\end{array}$ & $\begin{array}{l}\text { Gericht op betrokkenheid, vertrou- } \\
\text { wen, resultaten, en lange termijn }\end{array}$ \\
\hline
\end{tabular}

(Bron: gebaseerd op Davis e.a., 1997:37)

3 En dan hebben we het nog niet eens gehad over het feit dat er verschillende politieke principalen zijn: het parlement, de kiezer (die tevens klant kan zijn), het ministerie of een afdeling daarbinnen (Van Thiel \& Yesilkagit, 2011). 
Figuur 1 Relatiekeuzen voor principalen en uitvoerders (gebaseerd op Davis e.a., 1997)

\begin{tabular}{|c|c|c|c|}
\hline \multirow{4}{*}{ 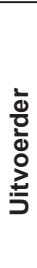 } & \multicolumn{3}{|c|}{ Principaal } \\
\hline & & PA-model & PS-model \\
\hline & PA-model & $\begin{array}{l}\text { Wederzijds wantrouwen, veel controle } \\
\text { en monitoring, gedetailleerde afspraken }\end{array}$ & $\begin{array}{l}\text { Principaal vertrouwt, maar agent is } \\
\text { opportunistisch: moral hazard }\end{array}$ \\
\hline & PS-model & $\begin{array}{l}\text { Steward voelt zich niet vertrouwd en te } \\
\text { veel gecontroleerd: dysfunctionele } \\
\text { relatie }\end{array}$ & $\begin{array}{l}\text { Wederzijds vertrouwen, sturing op } \\
\text { resultaten, afspraken op hoofdlijnen }\end{array}$ \\
\hline
\end{tabular}

Als we deze modellen gebruiken om de sturingsrelaties tussen ministeries en ZBO's te typeren, dan betekent dat dat we verwachten dat in een principaalstewardrelatie a) het ministerie en ZBO dezelfde (hogere) doelen en waarden of normen nastreven; b) het ZBO beschikt over een hoge mate van autonomie en zelfbeschikking; c) er meer sprake is van een horizontale dan hiërarchische relatie, bijvoorbeeld tot uiting komend in het betrekken van het $\mathrm{ZBO}$ bij het ontwikkelen van nieuw beleid (zgn. uitvoeringstoets); en d) wordt het ZBO alleen achteraf afgerekend op basis van resultaten (dus weinig ex ante-sturing). Kenmerkend voor deze vorm van sturen is: a) afspraken en sturing op hoofdlijnen, niet gedetailleerd; b) toezicht via anderen zoals een Raad van Toezicht; c) open overleg in een beperkte frequentie en met respect voor elkaars professionaliteit; en d) toestaan dat het $\mathrm{ZBO}$ een eigen $\mathrm{CAO}$ voert en/of marktactiviteiten ontplooit. Een gedragscode wordt in dit model gezien als een goed instrument omdat het leidt tot zelf-binding (in het Engels: bonding) door de uitvoerder.

In een principaal-agentbenadering daarentegen is sprake van: a) een groot machtsverschil tussen het $\mathrm{ZBO}$ en het ministerie (hiërarchische verhouding); b) veel ex ante-sturing en monitoring tijdens de taakuitvoering, bijvoorbeeld met behulp van prestatie-indicatoren; c) weinig samenwerking, bijvoorbeeld bij de totstandkoming van nieuw beleid; en d) beperkingen aan de autonomie van het ZBO. Dit betekent bijvoorbeeld dat het $\mathrm{ZBO}$ geen eigen $\mathrm{CAO}$ of marktactiviteiten mag hebben, dat de ministeriële verantwoordelijkheid zo volledig mogelijk opgaat (bijvoorbeeld door volledige toepassing van de Kaderwet ZBO's), geen Raad van Toezicht maar direct toezicht door het ministerie, en een hoge frequentie van overleg waarbij ook gedetailleerde informatie moet worden overlegd door het $\mathrm{ZBO}$. Het is belangrijk om te constateren dat het ene model niet beter hoeft te zijn dan het andere; zolang beide partijen in de relatie van hetzelfde model uitgaan, zal er sprake kunnen zijn van een goede relatie. Maar zodra de principaal en de uitvoerder van verschillende benaderingen uitgaan, ontstaan er dysfunctionele relaties (zie figuur 1). We komen later terug op dit punt.

Als een principaal de uitvoerder/steward als agent benadert (en dus wantrouwt), zal de steward zich onheus bejegend voelen door alle controle en monitoring die 
de principaal oplegt (vgl. Van Thiel, 2011 die dit het 'lege-nestsyndroom' noemt). Omgekeerd geldt dat een principaal die de uitvoerder/agent als een steward behandelt, ruim baan geeft aan de agent om moral hazard-gedrag te vertonen. De manier waarop beide partijen zich bejegend voelen en de wijze waarop zij de onderlinge relatie zien hangt sterk samen met de beoordeling van de onderlinge relatie en de prestaties door het $\mathrm{ZBO}$.

\section{Methoden}

Om inzicht te krijgen in de sturingsrelatie tussen ZBO's en ministeries is een kwalitatieve case study verricht bij vier ministeries en zes ZBO's; zie tabel 2 voor een overzicht. De organisaties variëren qua grootte, taak en leeftijd. De casussen zijn geselecteerd op basis van hun vermelding in het ZBO-register, ${ }^{4}$ zijn allen ingesteld bij wet, beschikken over eigen rechtspersoonlijkheid en vallen onder verschillende moederdepartementen. Het ministerie van VWS is als contrast geselecteerd omdat uit vooronderzoek bleek dat dit ministerie de relatie met het CAK op een afwijkende wijze invult en onderhoudt.

4 Het ZBO-register wordt bijgehouden door het Ministerie van Binnenlandse Zaken en Koninkrijksrelatie en bevat informatie over bestuursorganen zoals instellingsgrondslag, van toepassing zijnde wetgeving, rechtsvorm e.d. 
Tabel 2: $\quad$ Overzicht van onderzochte ZBO's

\begin{tabular}{|c|c|c|c|c|}
\hline ZBO & $\begin{array}{l}\text { Moederdepar- } \\
\text { tement }\end{array}$ & $\begin{array}{l}\text { Oprich } \\
\text { ting }\end{array}$ & $\begin{array}{l}\text { Omvang in } \\
2012\end{array}$ & Hoofdtaak \\
\hline $\begin{array}{l}\text { Landelijk Bureau } \\
\text { Inning Onderhouds- } \\
\text { bijdragen (LBIO) }\end{array}$ & $\begin{array}{l}\text { Veiligheid \& Justi- } \\
\text { tie }\end{array}$ & 1995 & $\begin{array}{l}86 \mathrm{fte} \\
5 \mathrm{~m} \text {-euro }\end{array}$ & $\begin{array}{l}\text { Het innen van partner- en } \\
\text { kinderalimentatie bij beta- } \\
\text { lingsplichtigen, en het vast- } \\
\text { stellen en innen van ouder- } \\
\text { bijdragen voor jeugdzorg. }\end{array}$ \\
\hline $\begin{array}{l}\text { Sociale Verzeke- } \\
\text { ringsbank (SVB) }\end{array}$ & $\begin{array}{l}\text { Sociale Zaken \& } \\
\text { Werkgelegenheid }\end{array}$ & 2004 & $\begin{array}{l}3.006 \mathrm{fte} \\
288 \mathrm{~m} \text {-euro }\end{array}$ & $\begin{array}{l}\text { Uitvoerder van volksverze- } \\
\text { keringen zoals kinderbijslag, } \\
\text { AOW-pensioen en nabe- } \\
\text { staandenuitkering ANW. }\end{array}$ \\
\hline $\begin{array}{l}\text { Uitvoeringsinstituut } \\
\text { Werknemersverze- } \\
\text { kering (UWV) }\end{array}$ & $\begin{array}{l}\text { Sociale Zaken \& } \\
\text { Werkgelegenheid }\end{array}$ & 2002 & $\begin{array}{l}16.600 \mathrm{fte} \\
1.8 \mathrm{~m} \text { - euro }\end{array}$ & $\begin{array}{l}\text { Uitvoeren van diverse wet- } \\
\text { ten voor werklozen, } \\
\text { arbeidsongeschikten, zieke } \\
\text { werknemers en arbeidsge- } \\
\text { handicapten (WIA, WAO, } \\
\text { ZW, WW, etc.). }\end{array}$ \\
\hline $\begin{array}{l}\text { Luchtverkeerslei- } \\
\text { ding Nederland } \\
\text { (LVNL) }\end{array}$ & $\begin{array}{l}\text { Infrastructuur \& } \\
\text { Milieu }\end{array}$ & 1993 & $\begin{array}{l}862 \mathrm{fte} \\
179 \text { m-euro }\end{array}$ & $\begin{array}{l}\text { Het veilig en efficiënt afhan- } \\
\text { delen van het luchtverkeer } \\
\text { op en rond de luchthavens } \\
\text { Schiphol, Zestienhoven, } \\
\text { Eelde en Maastricht, en } \\
\text { boven Nederland < } 24.500 \\
\text { voet. }\end{array}$ \\
\hline $\begin{array}{l}\text { Centraal Bureau } \\
\text { Rijvaardigheidsbe- } \\
\text { wijzen (CBR) }\end{array}$ & $\begin{array}{l}\text { Infrastructuur \& } \\
\text { Milieu }\end{array}$ & $\begin{array}{l}2013 \\
(1927)\end{array}$ & $\begin{array}{l}1040 \mathrm{fte} \\
115 \text { m-euro }\end{array}$ & $\begin{array}{l}\text { Het beoordelen van rijvaar- } \\
\text { digheid en medische } \\
\text { geschiktheid van bestuur- } \\
\text { ders en vakbekwaamheid } \\
\text { van professionals in trans- } \\
\text { port en logistiek. }\end{array}$ \\
\hline $\begin{array}{l}\text { Centraal Admini- } \\
\text { stratiekantoor bij- } \\
\text { zondere ziektekos- } \\
\text { ten (CAK) }\end{array}$ & $\begin{array}{l}\text { Volksgezondheid } \\
\text { Welzijn \& Sport }\end{array}$ & $\begin{array}{l}2013 \\
(1968)\end{array}$ & $\begin{array}{l}\text { I } 100 \text { perso- } \\
\text { neel } \\
96 \text { m-euro }\end{array}$ & $\begin{array}{l}\text { Vaststelling en inning van } \\
\text { bijdragen en/of tegemoet- } \\
\text { komingen en verstrekkin- } \\
\text { gen in het kader van } \\
\text { AWBZ en WMO. }\end{array}$ \\
\hline
\end{tabular}

Noot: oprichtingsdata betreffen meestal het jaar waarin de organisatie wettelijk is aangewezen als ZBO; bij budgetten wordt niet altijd een onderscheid gemaakt tussen apparaats- en programmakosten.

De inhoud van documenten (zoals bestuursreglementen, sturingsprotocollen, en instellingswetten) is geanalyseerd, voor zover zij informatie over aansturing en aansturingsarrangementen tussen ministerie en ZBO bevatten. Hieruit is informatie verzameld die van belang was om een beeld te vormen van de wederzijdse sturing. Ook zijn er semigestructureerde interviews gehouden met twaalf respondenten van zowel ministeries als ZBO's, die belast zijn met het onderhouden van de contacten over en weer. De interviews zijn uitgewerkt tot een transcript en teruggekoppeld aan de respondenten. Bij deze respondenten is ook een lijst met stellingen afgenomen waarbij zij een score konden geven op een zevenpuntsschaal om de relatie kwantificeerbaar en dus beter vergelijkbaar te maken (voor meer details zie Hendriks, 2013). Het onderzoek is uitgevoerd in de periode april- 
Aansturing van zelfstandige bestuursorganen door ministeries: stijlverschillen

augustus 2013. Wijzigingen in de organisatie van de sturingsrelaties na augustus 2013 zijn niet meegenomen.

\section{Resultaten}

We vatten hier de bevindingen uit de cases op hoofdpunten samen, eerst per ministerie en daarna vergeleken tussen de ministeries. Geïnteresseerde lezers kunnen in Hendriks (2013) alle resultaten in meer details nalezen.

\section{Infrastructuur en Milieu}

Vanwege de fusie van de ministeries van V\&W en VROM, heeft het ministerie van I\&M per 1 januari 2013 alle sturingsrelaties met ZBO's opnieuw ingericht. ${ }^{5}$ Daarbij is voor een aantal principes gekozen. Zo zijn de rollen tussen opdrachtgever en eigenaar standaard gescheiden. De eigenaarsrol is belegd bij de secretaris-generaal, die hiervoor ambtelijk wordt ondersteund door de Unit Toezicht. De opdrachtgeversrol wordt vervuld door het directoraat-generaal dat inhoudelijk met het beleid is belast dat wordt uitgevoerd; in het geval van het CBR en de LVNL is dat DG Bereikbaarheid. De sturingsrelaties zijn ook vastgelegd in verschillende documenten, zoals sturingsprotocol, toezichtsvisie, en informatiestatuut. Hierin worden afspraken vastgelegd over overlegstructuren, verantwoordingscycli, prestatieafspraken, tariefvaststelling, en werken voor derden. Prestatieafspraken en bijbehorende prestatieindicatoren worden in gezamenlijkheid opgesteld. In beide relaties is sprake van regelmatig overleg: op bestuurlijk niveau een paar maal per jaar, met de Unit Toezicht wat frequenter, tot dagelijkse contacten op medewerkerniveau afhankelijk van de noodzaak.

In tegenstelling tot het kabinetsbeleid heeft I\&M ervoor gekozen om Raden van Toezicht in stand te houden. Het kabinetsbeleid onderschrijft de Kaderwet ZBO's die alle bevoegdheden die normaliter aan een Raad van Toezicht worden toebedeeld, aan de minister toeschrijft (Van Ammers \& Van Thiel, 2012). De respondenten van I\&M en de verwante ZBO's zijn echter allen voorstander van een Raad van Toezicht, als klankbord voor de Raad van Bestuur van de ZBO's en als extra controleur voor de minister. Er is nog een uitzondering gemaakt op de Kaderwet: zowel bij het CBR als de LVNL is een uitzondering gemaakt voor de rechtspositie, en beide ZBO's voeren een eigen CAO. Voor alle overige zaken is de Kaderwet wel van toepassing. Er zijn ook een paar verschillen in de sturingsrelatie tussen de twee ZBO's. Zo heeft de LVNL vanwege internationale afspraken een ruimer mandaat om te werken voor derden (bijv. luchtvaartmaatschappijen of lokale overheden). En het CBR moet toestemming vragen voor besluiten over investeringen. De LVNL onderschrijft de gedragscode van de Handvest-groep ${ }^{6}$ maar is daar geen lid van.

5 Uit ander onderzoek weten we dat deze uitgangspunten ook voor de RDW gelden (De Kruijf \& Van Thiel, 2013).

6 Zie www.publiekverantwoorden voor meer informatie. 
In beide relaties wordt gesproken over vertrouwen als een belangrijke basis. Bij het CBR is dat een tijd minder goed geweest; door bestuurlijke, arbeidsrechtelijke en financiële problemen is een tijd sprake geweest van verscherpt toezicht door het ministerie, maar inmiddels zijn de problemen voorbij en de verhoudingen genormaliseerd. Er is een gedeeld besef bij alle respondenten dat communicatie belangrijk is voor een goed functioneren en het voorkomen van conflicten. Het is overigens belangrijk om te vermelden dat beide ZBO's volledig tariefgefinancierd zijn en geen financiële middelen ontvangen van het moederdepartement. Er worden uiteraard afspraken gemaakt over tariefbepaling, begroting en verantwoording, maar die zijn geen integraal onderdeel van de reguliere begrotingscyclus van de rijksoverheid.

\section{Sociale Zaken en Werkgelegenheid}

In 2011 zijn nieuwe afspraken gemaakt over de sturingsrelatie met ZBO's (in elk geval met het UWV en de SVB). Aanleiding voor die herziening was een onderzoek naar de sturingsrelatie. Daaruit bleek onder andere dat de relatie, vooral met het UWV, erg 'intensief' was en dat het inzicht in de rolverdeling enigszins kwijt was. Een van de voornaamste uitgangspunten bij de herziening was een duidelijkere scheiding van rollen: twee DG's zijn nu allebei opdrachtgever voor zowel het UWV als de SVB, en de eigenaar is de SG. Toezicht wordt gehouden door de afdeling Sturing ZBO's van de directie Uitvoering Beleid en Naleving van het ministerie. Deze afdeling lijkt echter nog meer te doen; ze faciliteert alle contacten tussen het ministerie en ZBO's, of wil in elk geval op de hoogte blijven van alle contacten en de uitkomsten daarvan. In het geval van de SVB zijn de nieuwe afspraken vastgelegd in een notitie, bij het UWV is dat minder eenduidig geregeld. Beide ZBO's hebben inspraak bij het opstellen van prestatieafspraken maar uiteindelijk zijn het toch vooral afspraken die het ministerie belangrijk vindt. Door de druk om te bezuinigen ligt de nadruk in de sturingsrelatie erg op kostenaspecten. Er is veel overleg, met name met het UWV. Daarin komen ook allerlei zaken met betrekking tot de bedrijfsvoering aan de orde, zoals bijvoorbeeld ICT (UWV) of de prioritering van uitvoeringstaken (SVB). Dat gaat dus verder dan sturen op hoofdlijnen.

De twee ZBO's worden meer betrokken bij de implementatie van nieuw beleid - onder andere door het doen van uitvoeringstoetsen op haalbaarheid en kosten van nieuw beleid - dan bij de inhoudelijke ontwikkeling daarvan. Ook hier geven respondenten aan dat het ministerie de boventoon voert bij de ontwikkeling van beleid. De relatie is daarmee hiërarchischer dan bij I\&M het geval is. Respondenten aan beide zijden van de relatie vinden dit overigens een vanzelfsprekend gegeven. De Kaderwet ZBO's is van toepassing op beide ZBO's, met uitzondering van de rechtspositieregeling. Beide ZBO's voeren een eigen $\mathrm{CAO}$ (dit is terug te voeren op privaatrechtelijke voorgangers van de organisaties). Er is geen Raad van Toezicht, maar de SVB heeft zelf een Raad van Advies ingesteld. De SVB lijkt ook op andere punten iets meer autonomie te hebben of nemen. Zo is de SVB lid van de Handvest-groep en onderschrijft de bijbehorende gedragscode. En de SVB heeft ruimere mogelijkheden om te werken voor tweeden (=andere overheden) dan het UWV. Belangrijk om nog te vermelden is dat het hier gaat om twee omvangrijke 
ZBO's, zowel in personele aantallen als financieringsstromen. Bron van financiering zijn premies en volksverzekeringen, geld dat deels ook buiten de begroting van SZW om gaat. De omvang en taak van beide ZBO's maakt dat ze zeer politieken mediagevoelig zijn.

\section{Veiligheid \& Justitie}

V\&J heeft eigenlijk geen systeem voor het relatiemanagement met zijn ZBO's. ${ }^{7}$ Het ministerie stuurt het LBIO eens per jaar een kaderbrief waarin allerlei afspraken eenzijdig worden bepaald, over salarissen, ziekteverzuim, aantallen inningen, etcetera. De meeste van deze indicatoren betreffen input of procesaspecten; er wordt weinig op resultaten gestuurd. De respondenten van het LBIO geven aan dat zij weinig tot geen inspraak hebben in het opstellen van de kaderbrief. Er is geen vaste overlegstructuur, maar er zijn wel frequente contacten. Het feit dat het LBIO is voortgekomen uit het ministerie (voormalige directie) en dat het een kleine organisatie is, maakt dat de lijnen kort en bekend zijn. Alleen voor de financiële controle bestaat een gedocumenteerd protocol. Momenteel is er nog een Raad van Toezicht, maar het ministerie heeft voorgesteld die af te schaffen in het kader van de toepassing van de Kaderwet ZBO's op het LBIO. Het ZBO betreurt dat.

$\mathrm{Al}$ met al zet vooral het ministerie de toon in de relatie. Er zijn veel wetten en regelingen die de taken van het LBIO nauwkeurig omschrijven. Binnen die kaders heeft het LBIO wel enige autonomie, maar het ZBO heeft weinig invloed op de kaders zelf. Zo wordt het LBIO wel gevraagd om een reactie over nieuwe beleidsplannen, maar dit betreft geen formele uitvoeringstoets en het is ook geen vorm van inspraak of participatie.

\section{Volksgezondheid, Welzijn en Sport}

VWS heeft geen splitsing aangebracht tussen de rollen van eigenaar en opdrachtgever. ${ }^{8}$ Beide rollen zijn, voor de relatie met het CAK, belegd bij het DG Langdurige zorg. Wel zijn er bij andere afdelingen accounthouders ${ }^{9}$ aangewezen die belast zijn met het uitwisselen van informatie over beleidsontwikkelingen en het onderhoud van de relaties tussen VWS en ZBO's. Deze relaties zijn allemaal vastgelegd in een governance arrangement. Naast toezicht door het ministerie zelf, houden ook de zorgautoriteit NZA en het Zorginstituut Nederland (voorheen CVZ) toezicht op het CAK. Het CAK heeft een Raad van Advies en is lid van de Handvestgroep Publiek Verantwoorden. Er is een overlegstructuur vastgelegd, evenals afspraken over de financiële controles (audit). Ook kent het CAK het instrument van de uitvoeringstoets waardoor invloed kan worden uitgeoefend op

7 De eerste auteur was jarenlang lid van de Raad voor Rechtsbijstand, een ZBO dat ook onder dit ministerie valt. Het beeld uit de case study bij het LBIO komt sterk overeen met haar ervaringen met de sturingsrelatie aldaar.

8 In 2014 is die splitsing wel gemaakt.

9 Een dergelijk model is ontleend aan het accountmanagement; één contactpersoon is aanspreekbaar voor alle contacten. VWS hanteert dit model ook voor andere ZBO's, zoals de Nederlandse Zorgautoriteit (NZA). 
de ontwikkeling van nieuw beleid. Er zijn geen formele prestatieafspraken. Het CAK heeft wel in overleg met het ministerie prestatie-indicatoren opgesteld en rapporteert daar over aan het ministerie.

Het CAK is per 2013 een publiekrechtelijk ZBO geworden. De Kaderwet ZBO's is van toepassing met uitzondering van de rechtspositieregels; dat heeft te maken met de privaatrechtelijke voorganger van de organisatie. Aanleiding voor de herpositionering in 2013 was de onduidelijke governance structuur ${ }^{10}$ en uitvoeringsproblemen na wijzigingen in de AWBZ. Omdat de zorgwetgeving anno 2013 nog aan het veranderen was, was ten tijde van het onderzoek nog niet duidelijk wat de status en positie van het CAK in de nabije toekomst zou zijn. Aan de vertrouwensband tussen VWS en het CAK wordt gewerkt. Beide partijen beseffen dat dat belangrijk is maar de problemen uit het verleden hebben veel impact gehad. De cultuur van het ministerie (gericht op politiek) en van het ZBO (gericht op praktijk) sluiten ook niet altijd even goed op elkaar aan, aldus de respondenten.

\section{Overeenkomsten en verschillen}

Er zijn grote verschillen tussen de ministeries als het gaat om hoe zij de sturingsrelatie met hun ZBO's inrichten en onderhouden. ${ }^{11}$ De relatie tussen het Ministerie van I\&M en zijn twee ZBO's vertoont de meeste kenmerken van een principaal-stewardrelatie. Er is veel commitment bij beide partijen, zowel aan elkaar als aan het collectieve belang dat ze delen. Ministerie en ZBO's spreken over het vertrouwen dat ze in elkaar hebben. De ZBO's krijgen veel autonomie, maar ook inbreng in bijvoorbeeld nieuw beleid, en ze worden vooral op resultaten beoordeeld. De Ministeries van V\&J en VWS daarentegen hebben een typische principaal-agentverhouding tot hun ZBO's. Er is een grote machtsafstand en het belang van de politiek overheerst de relatie. Er wordt niet echt op resultaten gestuurd; input-afspraken worden top-down opgelegd (LBIO) of er zijn geen prestatieafspraken (CAK). De onvrede van respondenten van het LBIO over sommige zaken zou gezien kunnen worden als een wens om meer als steward behandeld te willen worden. Het CAK is bewust bezig met het (her)inrichten van de relatie met het moederdepartement, maar dat vereist ook een verandering in de houding van het ministerie en daar ziet het vooralsnog niet naar uit. Het Ministerie van SZW zit ertussenin, alhoewel de relatie met het UWV intensiever (meer principaalagent) lijkt dan met de SVB. Er wordt veel overlegd, ook over details, en de nadruk ligt sterk op kostenaspecten in plaats van resultaten. Ook hier is eerder sprake van hiërarchische verhouding dan van een horizontale relatie. Dat de SVB op een aantal punten een eigen koers vaart (Raad van Advies, Handvestgroep) lijkt te worden getolereerd door SZW.

10 CAK was opgericht als BV door een stichting van samenwerkende ziekenfondsen en private zorgverzekeraars voor de uitvoering van AWBZ-regelingen. In de loop der tijd waren echter ook andere taken aan het CAK opgedragen, door de minister of staatssecretaris via AMvB's. Toen uitvoeringsproblemen ontstonden bleek dat niet duidelijk was wie nu de eigenaar en opdrachtgever van de vennootschap waren.

11 Ministeries verschillen overigens ook in de aantallen ZBO's die ze oprichten en de wettelijke voorwaarden die ze daar aan verbinden (zie Van Thiel, 2006). 
Opvallend is dat drie van de vier ministeries recent (2011 of 2013) de sturingsrelatie opnieuw hebben ingericht. Soms was dit naar aanleiding van onderzoek naar de sturingsrelatie (SZW), soms naar aanleiding van een herpositionering van het ZBO (VWS), of door een departementale herschikking (I\&M). De afspraken zijn vastgelegd in documenten, zoals toezichtsvisies, sturingsprotocollen of informatiestatuten. Alleen voor het LBIO en het UWV bestaat geen expliciet document waarin zulke afspraken zijn vastgelegd. Twee ministeries hebben gekozen voor een duidelijke scheiding van rollen: I\&M en SZW. De rol van opdrachtgever ligt daar bij een beleidsdirectie of DG en de SG vervult de eigenaarsrol (ambtelijk uitgevoerd door de financiële afdeling of een speciale afdeling voor relatiebeheer, vgl. Plug e.a., 2004). In het verleden zijn er experimenten geweest met interfaceunits waarin deze rollen werden gecombineerd (Van Twist \& Plug, 1998), maar de meeste van die units zijn inmiddels weer opgeheven, bijvoorbeeld vanwege departementale herschikkingen, interne afstemmingsconflicten, of veranderingen bij de ZBO's (zie respectievelijk de interface unit van VROM voor het Kadaster, de afdeling RZO bij OCW [vgl. Van der Werf, 1994], en de accountmanagers bij BZK voor de politieregio's). Voordeel van een interface-unit is dat ZBO's één loket hebben voor al hun contacten en vragen. Het lijkt erop dat de afdeling Sturing ZBO's van SZW ook zo'n interface-functie probeert te vervullen, maar in combinatie met het model van de rollenscheiding maakt dat het geheel van sturingsrelaties wel erg complex. VWS benoemt wel dat er verschillende rollen zijn, maar belegt ze niet bij verschillende afdelingen. En V\&J spreekt niet in termen van rollen. Zonder te willen impliceren dat rollenscheiding het beste model is, is in elk geval wel duidelijk dat de ministeries sterk verschillen in de ontwikkeling van hun ideeën over sturingsrelaties, evenals in de organisatorische vormgeving daarvan.

Er zijn tal van documenten en instrumenten in omloop waarin of waarmee gestuurd in de relaties: sturingsprotocol of -notitie, governance arrangement, toezichtsvisie, informatiestatuut, kaderbrief, kaderwet, overlegstructuur, uitvoeringstoets, prestatieindicatoren, gedragscode, tariefbepaling, en verantwoordingsdocumenten zoals jaarverslag en jaarrekening. Ministeries verschillen in welke instrumenten ze gebruiken, hoe ze die noemen en ook hoe ze daarmee werken. Zo wordt een uitvoeringstoets door sommige ministeries (V\&J) alleen ex post gebruikt, dus nadat het beleid al is vastgesteld en alleen om haalbaarheid en kosten te berekenen, terwijl andere ministeries (I\&M) dit instrument ex ante inzetten in de fase waarin beleid nog ontwikkeld moet worden. Ook verschillen ministeries in de toepassing van de Kaderwet ZBO's, bijvoorbeeld het instellen van een Raad van Toezicht (zie I\&M versus SZW). In vijf van de zes ZBO's is sprake van een eigen $\mathrm{CAO}$; dat heeft te maken met de privaatrechtelijke oorsprong van deze organen en is daarom niet geheel representatief voor de totale populatie ( $40 \%$ van populatie $[\mathrm{N}=118]$ is privaatrechtelijk).

Ministeries verschillen niet alleen van elkaar in instrumentgebruik, maar maken ook verschillende keuzen voor verschillende ZBO's die onder hetzelfde ministerie vallen (zie bijv. verschillen tussen het UWV en de SVB). Waarschijnlijk heeft dit ook te maken met de persoon die verantwoordelijk is voor de sturingsrelatie, want 
in de onderzochte cases zijn dezelfde directies of DG's betrokken bij de cases. De rol van personen blijkt sowieso van belang te zijn in de sturingsrelaties, zo geven respondenten aan. Dat is niet verbazingwekkend want relaties en vertrouwen zijn sterk persoonsgebonden.

\section{Discussie}

In het voorgaande hebben we gezien dat ministeries verschillen in de inrichting en het onderhouden van sturingsrelaties met ZBO's. Hoe kunnen die verschillen worden verklaard?

Een belangrijke verklaring voor deze variatie is gelegen in het feit dat er geen centrale coördinatie plaatsvindt. In andere landen gebeurt dat wel. Zo stellen bijvoorbeeld de ministeries van Financiën en Ambtenarenzaken in Vlaanderen uniforme richtlijnen op voor zaken als verantwoording, personeelsbeleid en tariefstelling (Verhoest \& Van Thiel, 2004). In het Verenigd Koninkrijk speelt de Cabinet Office een cruciale rol (zie https://www.gov.uk/public-bodies-reform), bijvoorbeeld door het verplicht stellen van formats voor verantwoording, prestatieafspraken en evaluaties. In Nederland bestaat voor een andere vorm van verzelfstandiging, het oprichten van agentschappen, wel meer coördinatie namelijk door het Ministerie van Financiën. Ook heeft enige tijd een team van ambtenaren bestaan, van BZK en Financiën gezamenlijk (het zogenoemde BIFI-team) dat zorgde voor meer afstemming in het verzelfstandigingsbeleid, maar dat team is opgeheven. Dat betekent dat er geen centrale plaats is waar kennis over sturingsrelaties wordt opgeslagen en beschikbaar gemaakt voor andere ministeries. Ook is er geen handleiding, richtlijn of format waar ministeries gebruik van kunnen maken. ${ }^{12} \mathrm{ZBO}$ 's kennen wel samenwerkingsverbanden waar ze informatie met elkaar delen, zoals de Handvestgroep en de rijksbrede Benchmarkgroep, maar dat betreft meestal interne bedrijfsvoeringsaspecten en niet sturingsrelaties met moederdepartementen.

Een tweede verklaring betreft de houding of opvattingen van ministeries - of eigenlijk de ambtenaren die daar werken - ten aanzien van verzelfstandiging en ZBO's. Zo zagen we bijvoorbeeld grote verschillen in de opvattingen van I\&M en SZW over het instellen van een Raad van Toezicht. In het debat over ZBO's is al langer een strijd gaande tussen de uniformisten en pluralisten (Van Thiel, 2001). De uniformisten geloven in harmonisering van alle arrangementen ten aanzien van ZBO's, terwijl pluralisten de diversiteit van ZBO's belangrijk vinden en willen accomoderen. Dit verschil van opvatting heeft er bijvoorbeeld toe geleid dat er wel een Kaderwet ZBO's is, maar dat die niet verplicht of volledig hoeft te worden toegepast. Een derde aspect betreffende de houding of opvatting van ministeries heeft te maken met vertrouwen. Vertrouwen is een complex begrip en kent vele

12 In 1999-2002 heeft BZK wel een 'handleiding externe verzelfstandiging' gepubliceerd. Deze is echter niet aangepast na de inwerkingtreding van de Kaderwet, en daarmee waarschijnlijk niet meer geldig. 
definities (Bachmann \& Zaheer, 2006; Nooteboom, 2002). Volgens sommigen is het een basishouding, volgens anderen moet vertrouwen worden verdiend. De principaal-stewardbenadering vereist vertrouwen, maar niet iedereen zal in staat zijn om dat a priori te geven. Dit bleek bijvoorbeeld uit de mate waarin ministeries ZBO's betrekken bij de ontwikkeling van nieuw beleid, en met name in welk stadium van de beleidsontwikkeling ze dat doen (I\&M vroeg, V\&J laat). Het gebrek aan coördinatie maakt het mogelijk dat ministeries er zulke verschillende opvattingen en werkwijzen op na houden. Dit past overigens bij de aard van het Nederlandse bestuur: gedecentraliseerd en gericht op concensus. De eerste twee verklaringen hangen dus samen.

Een derde verklaring kan te maken hebben met het aantal ZBO's waar een ministerie mee te maken heeft, de omvang van die organen (bijv. in budget) en de financieringsstromen die ermee gepaard gaan. De twee ZBO's die onder I\&M vallen, zijn beide tariefgefinancierd. Dat draagt bij aan hun autonomie ten opzichte van het moederdepartement. Bij de ZBO's van SZW zagen we juist dat de omvang en doelgroep hen extra politiek gevoelig maakt, waardoor het ministerie meer behoefte aan grip op de ZBO's zal hebben. Bij het LBIO werd juist de kleine omvang van de organisatie door respondenten genoemd als reden voor de geringe autonomie. Kortom, het is aannemelijk dat aantal en omvang van ZBO's een rol spelen in de wijze waarop de sturingsrelatie wordt ingericht en onderhouden. Op basis van zes cases is het echter niet mogelijk te bewijzen of dit zo is en zo ja, hoe het werkt; daarvoor is meer onderzoek nodig. Dat het verleden en de oorsprong van een $\mathrm{ZBO}$ ook van invloed is op de huidige relatie met het moederdepartement, wordt door meerdere auteurs aangegeven (Pollitt, 2004; vgl. Christensen \& Laegreid, 2006). Dit sluit aan bij de tweede en derde verklaring omdat eerdere ervaringen in de relatie en lange termijn kenmerken van ZBO's doorwerken in de relaties nu. De voorbeelden van het CBR en het CAK laten dit zien; daar kost het opbouwen van vertrouwen na een problematische situatie tijd. Ook het feit dat meerdere ZBO's een privaatrechtelijke voorganger hadden, werkt door in bijvoorbeeld de afwijkende rechtspositieregelingen.

Een laatste verklaring voor de verschillen tussen ministeries kan worden gevonden in externe omstandigheden. Departementale herschikkingen waren bijvoorbeeld aanleiding voor I\&M om de relaties met ZBO's opnieuw te beschouwen. Ook beleidswijzigingen (zoals de AWBZ in het geval van het CAK) of bezuinigingen (zoals bij SZW) leiden tot aanpassing van arrangementen en afspraken. Niet alle ministeries worden in dezelfde mate geraakt door dit soort gebeurtenissen. Een belangrijke katalysator voor veranderingen zijn beleidscrises, zeker als er ook veel media-aandacht bij komt.

Eerder werd gesteld dat als beide partijen voor dezelfde uitgangspunten van een sturingsmodel kiezen, er sprake is van duidelijkheid en overeenkomende verwachtingen en bejegening. Als er verschillende keuzen worden gemaakt, kunnen er dysfunctionele relaties ontstaan. Bij I\&M lijken zowel het ministerie als de ZBO's een principaal-stewardbenadering te hanteren en te waarderen. In het geval van V\&J lijkt het LBIO zich te conformeren aan de principaal-agentkenmer- 
ken van de relatie. Maar in de relaties bij SZW en VWS worden door de ZBO's wel signalen afgegeven dat ze zich meer als steward opstellen dan ze worden behandeld. Dit is het meest duidelijk bij CAK (verantwoording over prestaties) en de SVB (gedragscode, autonomie), en wat minder bij het UWV. Het is niet altijd duidelijk op grond waarvan ministeries kiezen voor een bepaalde stijl van aansturen, of hoe bewust zo'n keuze is. Onze bevindingen laten zien dat het belangrijk is dat ministeries en ZBO's hun voorkeur voor een bepaalde aansturingswijze expliciteren, en op elkaar afstemmen. Een eenduidige keuze voor een sturingsmodel maakt de verwachtingen aan beide zijden van de relatie duidelijk en verkleint de kans op dysfunctionaliteiten.

Ministeries die een principaal-stewardrelatie willen nastreven, zouden samen met hun ZBO's afspraken moeten maken. Dat bevordert het commitment en vertrouwen tussen ZBO's en ministeries. In een principaal-agentbenadering is eenzijdige vaststelling van sturing en monitoring mogelijk, al kan dat door de informatieasymmetrie betekenen dat het ministerie niet de juiste afspraken maakt met alle risico's van dien (moral hazard, adverse selection). In beide soorten relaties is het belangrijk dat afspraken worden vastgelegd, zodat ook bij personele wisselingen continuïteit kan worden gegarandeerd. En er moet rekening worden gehouden met omstandigheden die van belang zijn, van geval tot geval. Het openbaar maken van dergelijke afspraken kan andere ministeries en ZBO's helpen bij het inrichten van hun sturingsrelatie - en het maakt onderzoek naar dit onderwerp mogelijk, want op dit moment is informatie over dit onderwerp nauwelijks te traceren (in tegenstelling tot bijvoorbeeld België [waar prestatieafspraken in het Staatsblad worden gepubliceerd] en het Verenigd Koninkrijk [driejaarlijkse reviews van alle non-departmental bodies [NDPBs] zijn in te zien via de website: https://www.gov.uk/government/collections/triennial-review-reports]).

\section{Conclusies}

Dit artikel begon met de constatering dat er kritiek is op hoe ministeries hun sturingsrelatie met ZBO's inrichten. We hebben laten zien dat er (grote) verschillen zijn. Ministeries verschillen bovendien ook in de ontwikkeling van die relaties; sommigen zijn veel verder dan anderen bijvoorbeeld in de ontwikkeling van (nieuwe) instrumenten, samenwerken bij nieuw beleid, en het maken van (prestatie)afspraken. Het verweer van het kabinet op de kritiek klopt wel enigszins; in de afgelopen jaren is er vooruitgang geboekt, maar niet bij alle ministeries. En omdat er geen kennis wordt uitgewisseld waar de 'achterblijvers' van zouden kunnen leren, is het maar de vraag of de (uniformerende) circulaire die het kabinet heeft beloofd hiervoor een oplossing gaat zijn. Ministeries verschillen nu eenmaal, zowel in het aantal als de omvang van ZBO's, in hun houding ten opzichte van verzelfstandiging, en hun stijl van sturen. Het lijkt vooral belangrijk dat ministeries en ZBO's voor dezelfde soort sturingsrelatie kiezen, ongeacht of dat nu een principaal-agent- of principaal-stewardmodel is. Als twee partijen in een relatie 
voor tegengestelde uitgangspunten kiezen, wordt het immers nooit een goede relatie.

\section{Literatuur}

Bachmann, R. \& A. Zaheer (eds.), Handbook of trust research, Cheltenham: 2006.

Besley, T., Principled agents? The political economy of good government, Oxford: 2006.

Block, P., Stewardship. Choosing service over self-interest, San Francisco: 1996.

Christensen, T. \& P. Laegreid. (eds.), Autonomy and Regulation. Coping with agencies in the modern state, Cheltenham: 2006.

Davis, J.H., F.D. Schoorman \& L. Donaldson, 'Toward a stewardship theory of management', The Academy of Management Review, 1997/1, p. 20-47.

Hendriks, R.H.P., De aansturing van zelfstandige bestuursorganen door departementen. De governance structuur van departementen in vergelijkend perspectief, scriptie, Radboud Universiteit, Nijmegen: 2013.

Hendrikse, G.W.J., Coördineren en motiveren. Een overzicht van de economische organisatietheorie, Schoonhoven: 1993.

Homburg, V.M.F. \& S. van Thiel, 'Lessen en inzichten voor zbo-beleid', Openbaar Bestuur, 2002/2, p. 21-24.

Kabinetsreactie op het rapport 'Verbinding Verbroken?' van de Onderzoekscommissie Privatisering en Verzelfstandiging Overheidsdiensten van de Eerste Kamer en het rapport 'Publieke Zaken in de marktsamenleving van de Wetenschappelijke Raad voor het Regeringsbeleid', brief van het kabinet aan de voorzitter van de Tweede Kamer der Staten-Generaal, 26 maart 2013.

Kruijf, J. de \& S. van Thiel, Keurslijf of maatpak? Over verschillen in aansturing en dienstverlening tussen Agentschappen en Zelfstandige Bestuursorganen, rapport op verzoek van de Raad van Toezicht van de RDW, vertrouwelijk rapport, Nijmegen: 2009.

Laffont, J.-J. \& D. Martimort, The theory of incentives. The principal-agent model, Princeton: 2002.

Miller, G. J., 'The political evolution of principal-agent models', Annual Review of Political Science, 2005/8, p. 203-225.

Ministerie van BZK, Het kabinetsbeleid ten aanzien van zbo's, brief van het kabinet aan de voorzitter van de Tweede Kamer der Staten-Generaal, 13 mei 2014 (met bijlage).

Nooteboom, B., Trust. Forms, foundations, functions, failures and figures, Cheltenham: 2002.

Parlementaire Onderzoekscommissie (POC), Verbinding verbroken? Onderzoek naar de parlementaire besluitvorming over de privatisering en verzelfstandiging van overheidsdiensten, Eerste Kamer, vergaderjaar 2012-2013, B en C, Den Haag: 2012.

Plug, P.J., R. Timmerman, A. Dekker, S. Fooij \& S. ten Have, Aansturen van verzelfstandigde organisaties. Het creëren van effectieve verbindingen tussen beleid en uitvoering, bureau Berenschot, Assen: 2004.

Pollitt, C., 'Ministries and agencies. Steering, meddling, neglect and dependency', M. Painter \& J. Pierre (eds.), Challenges to state capacity. Global trends and comparative perspectives, Basingstoke: 2005, p. 112-136.

Pratt, J.W. \& R.J. Zeckhauser, Principals and agents, Boston: 1991.

Rapport De Leeuw, Onderzoek naar de herpositionering van ZBO's, Den Haag: 2013.

Schillemans, T., De belangentegenstelling voorbij. Theoretische inzichten en praktische aanbevelingen voor het organiseren van vertrouwen tussen beleid en uitvoering, onderzoek in opdracht van het ministerie van BZK, USBO, Utrecht: 2010. 
Ammers, M. van \& S. van Thiel, 'Kaderwet Zelfstandige Bestuursorganen. Het einde van Raden van Toezicht als toezichthouders bij ZBO's?', Bestuurswetenschappen, 2012/4, p. 35-54.

Thiel, S. van, 'Kaderwet zelfstandige bestuursorganen. Uniformiteit of verscheidenheid?', Bestuurswetenschappen, 2001/2, p. 189-193.

Thiel, S. van, 'Styles of reform. Differences in agency creation between policy sectors in the Netherlands', Journal of Public Policy, 2006/2, p. 115-139.

Thiel, S. van, The empty nest syndrome. Dutch ministries after the separation of policy and administration, paper gepresenteerd op IRSPM 12, , Brisbane: 26-28 maart 2008.

Thiel, S. van, 'Besluitvorming over verzelfstandiging. Een ontwerp', Bestuurskunde, 2010/3, p. 65-76.

Thiel, S. van, 'The empty nest syndrome. Dutch ministries after the separation of policy and administration', S. Van de Walle \& S.M. Groeneveld (eds.), New steering concepts in public management, Bingly: 2011, p. 25-40.

Thiel, S. van \& K. Yesilkagit, 'Good neighbours or distant friends. Trust between Dutch ministries and their executive agencies', Public Management Review, 2011/6, p. $783-802$.

Thiel, S. van, S. Soetekouw, M. Dresmé \& P. van Goch (in review), ZBO-evaluaties. Verplicht, verzuimd, en veronachtzaamd?

Twist, M.J.W. van \& P.J. Plug, 'Een moeizame verbinding. Over de vormgeving van interfaces bij kerndepartementen', Beleidsanalyse, 1998/3, p. 15-22.

Verhoest, K. \& S. van Thiel, 'Herstel van het primaat van de politiek: een vergelijking van de ontwikkelingen in het beleid rondom verzelfstandigde organisaties in Nederland en Vlaanderen', Beleid en Maatschappij, 2004/1, p. 27-41.

Werf, J. van der, 'Relatiemanagement bij het Ministerie van Onderwijs, Cultuur en Wetenschappen', S. van Thiel (ed.), Governance van uitvoeringsorganisaties. Nieuwe vraagstukken voor sturing in het publieke domein, publicatie van het Kadaster, Apeldoorn: 2004, p. 77-86. 